\title{
Correlation between Teenage Nutrition Knowledges in Preventing COVID-19
}

\author{
Duwi Sulistiani $^{1}$, Sri Ratna Rahayu ${ }^{2}$, Ari Yuniastuti ${ }^{3}$ \\ \{sulistianidwi01@gmail.com ${ }^{1}$, sriratnarahayu@mail.unnes.ac.id ${ }^{2}$, ari_yuniastuti@yahoo.co.id ${ }^{3}$ \} \\ Universitas Negeri Semarang, Semarang, Indonesia ${ }^{1,2,3}$
}

\begin{abstract}
Corona virus is now endemic in various parts of the world including Indonesia. The number of patients is increasing every day, because its spread is relatively fast and difficult to detect. As an effort to prevent COVID-19, optimal body defense is needed. One of them by consuming balanced nutritional food. The purpose of this study was to determine the relationship of nutritional knowledge in adolescents in the prevention of Covid-19. This research uses a quantitative approach with cross sectional study design. The sample size of 35 teenage respondents was selected by simple random sampling. The results of the study that there is a relationship between nutritional knowledge in adolescents in the prevention of COVID-19 with a value of $p=\leq 0.05$.
\end{abstract}

Keywords: nutritional knowledge, adolescents, Covid-19 prevention

\section{$1 \quad$ Introduction}

Virus is now endemic in the world, including Indonesia. The number of patients is increasing every day, because its spread is relatively fast and difficult to detect. This was stated in the Journal of Autoimmunity that "Coronavirus is one of the major pathogens that primarily targets the human respiratory system. Previous outbreaks of coronaviruses (CoVs) include the severe acute respiratory syndrome (SARS) - CoV and the Middle East respiratory syndrome (MERS) - $\mathrm{CoV}$ which have been previously characterized as agents that are a great public health threat. In late December 2019, a cluster of patients was admitted to hospitals with an initial diagnosis of pneumonia of an unknown etiology. These patients were epidemiologically linked to a wholesale seafood and wet animal market in Wuhan, Hubei Province, China. Early reports predicted the onset of a potential Coronavirus outbreak given the estimate of a reproduction number for the 2019 [1] which was deemed to be larger greater than 1[2]. From the journal information was obtained that the corona virus (Covid-19) is a collection of viruses that can infect the respiratory system. In many cases, this virus only causes mild respiratory infections, such as flu. However, this virus can also cause severe respiratory infections, such as lung infections (pneumonia), Middle-East Respiratory Syndrome (MERS), and Severe Acute Respiratory Syndrome (SARS) to death. This virus infection is called COVID-19 and was first discovered in the city of Wuhan, China, at the end of December 2019. This virus spread quickly and has spread to other regions in China and to several countries, including Indonesia [3]. 
Common signs and symptoms of Covid-19 infection include symptoms of acute respiratory disorders such as fever, coughing and shortness of breath. The average incubation period is 5-6 days with the longest incubation period of 14 days. In severe cases COVID-19 can cause pneumonia, acute respiratory syndrome, kidney failure, and even death. The clinical signs and symptoms reported in the majority of cases are fever, with some cases having difficulty breathing, and X-rays show extensive pneumonia infiltrates in both lungs [4] Covid-19 is now a serious world problem with the number of cases that is always increasing every day. Attack everyone regardless of age or gender and has been categorized as a global pandemic [5].

According to the [6], the Covid-19 problem has been experienced by almost all countries with a total of 827,419 exposed to the corona virus and 40,777 dead. COVID-19 attacks all ages and the majority affects young adults / teenagers. This is based on a journal published by Elsevier Ltd that "The age of patients was from 6 months to 94-year-old, the mortality of patients were young adults $(77.4 \%)$, there was no significant difference between male and female in our study, population was generally susceptible" [7]. In Indonesia, there were 114 positive cases, bringing the total to 1,528 cases, 6 of the co-19 patients recovered, and 14 cases of death. There are 32 provinces exposed to the corona virus, one of which is Central Java Province [8]. There were 92 positive cases in Central Java Province, 92 cases treated, 77 cases treated, 8 cases recovered, 7 cases died, ODP (monitoring people) 9,434 cases and PDP (patients under surveillance) as many as 406. The prevalence of having the highest cases of covid- 10 or included in the red zone where ODP 700, PDP 54 and Positive 6, namely Semarang City.

The body's defense against viruses must be strengthened by consuming vitamins and minerals that contain vitamins A, B, C, D, E, omega 3 fatty acids, selenium, zinc, iron and copper [9] Consumption of vegetable and animal protein, reduce sugar intake, do physical activity for 30 minutes, 3-5 times a week, always get sunlight for 5-15 minutes, always happy thinking and happy thinking [8]. Viewed from a number of relevant previous studies indicate that there have been efforts to improve the balance of energy intake and nutrients in adolescents. Research by [10], [11] showed an imbalance in energy intake in adolescents due to lack of knowledge about nutritional needs and unequal distribution of nutrients for carbohydrates, proteins and fats. Also indicative of the lack of consumption of vegetables and fruit. [12], [13], studied the assessment of nutritional status using a 24-hour recall food intake survey method by a nutritionist and the Body Mass Index (BMI) anthropometric assessment.

From the explanation above mentioned one of the prevention is by consuming nutritious food and maintaining personal hygiene. Communities are encouraged to adopt a regular diet every day by fulfilling the principle of balanced nutrition consisting of carbohydrates / staple foods, animal protein, vegetable protein and vegetables, as well as fruits that can be used as healthy snacks [14]. Based on the above problem, the researcher is interested in examining Adolescent Nutrition Knowledge in Covid-19 Prevention.

\section{Methods}

This research uses a quantitative approach with cross sectional study design. The population in this study were all adolescents in the city of Semarang. Sampling is done by simple 
random sampling technique. The dependent variable is COVID-19 prevention and the independent variable is nutritional knowledge. The sample in this study amounted to 35 teenage respondents in the city of Semarang who were selected using purposive sampling. Data collection using a questionnaire which is assisted by the Google Form program. Data analysis was performed univariately and bivariately (chi-square test).

\section{$3 \quad$ Results and discussions}

Nutrition knowledge is one of the factors that determine a person's food consumption. People who have good nutritional knowledge will have the ability to apply nutritional knowledge in food selection and processing so that food consumption can be expected to be guaranteed.

Table 1. Frequency of respondents knowledge of adolescent nutrition

\begin{tabular}{lccc}
\hline Knowledge Category & $\mathbf{N}$ & \% \\
\hline Low & & 9 & 25,7 \\
Good & Total & 26 & 74,3 \\
\hline & 35 & 100 \\
\hline
\end{tabular}

Table 1. Shows that as many as 9 people $(25.7 \%)$ of respondents had less knowledge of adolescent nutrition, 26 people $(74.3 \%)$ of respondents were well-informed about adolescent nutrition. This shows that the majority of adolescents have sufficient nutritional knowledge and below grafic of above data.

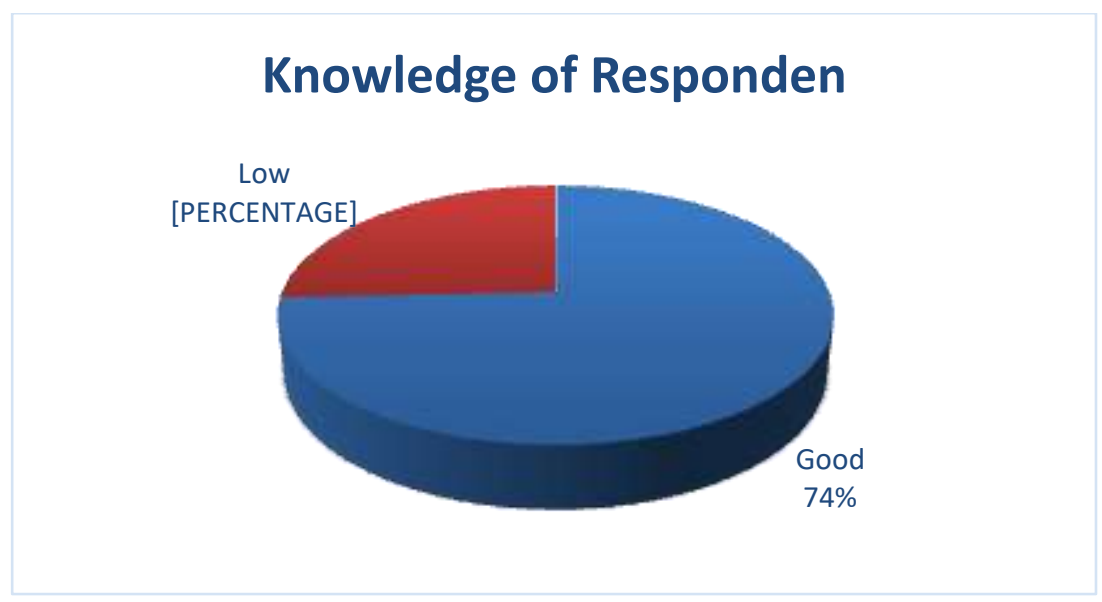

Fig. 1. Data of knowledge of responden concerning COVID-19 prevention

From above data, 26\% knowledge of responden are low and 74\% knowledge of responden are good. A person's level of nutritional knowledge influences attitudes and behaviors in food selection, which in turn will affect the nutritional state in question and influence the for- 
mation of one's eating habits [15] Inadequate nutritional knowledge, lack of understanding of nutrition, good eating habits, and lack of understanding of the nutritional contribution of various types of food will cause problems to intelligence and productivity [16].

Adequate knowledge of adolescent nutrition is related to the availability of reading facilities and information facilities in schools, such as libraries, computer laboratories and multimedia rooms that support students to always access the latest information. Formal education is a major factor influencing one's knowledge including knowledge about nutrition and health. The higher the level of education, the easier it will be to absorb nutrition and health information so that nutrition and health knowledge will be better [17].

Tabel 2 : Relationship of adolescent nutrition knowledge in COVID-19 prevention

\begin{tabular}{|c|c|c|c|c|c|c|c|}
\hline \multirow{3}{*}{ Variabel } & \multicolumn{4}{|c|}{ Knowledge Category } & \multirow{2}{*}{\multicolumn{2}{|c|}{ Total }} & \multirow{3}{*}{$\boldsymbol{P}$} \\
\hline & \multicolumn{2}{|c|}{ Low } & \multicolumn{2}{|c|}{ Good } & & & \\
\hline & $\mathbf{n}$ & $\%$ & $\mathbf{N}$ & $\%$ & $\mathbf{n}$ & $\%$ & \\
\hline COVID Prevention & & & & & & & \multirow{3}{*}{0,000} \\
\hline Prevention & 0 & & 26 & 74,3 & 26 & 100 & \\
\hline Not Prevention & 9 & 25,7 & 0 & & 9 & 100 & \\
\hline
\end{tabular}

From table 2. it is known that of the 26 respondents with good knowledge of adolescent nutrition against those who prevent, while adolescent nutritional knowledge there are 9 respondents who are not babbling. Based on the results of statistical tests using the chi square obtained value $\mathrm{p}=0,000$. These results indicate that there is a relationship between adolescent nutritional knowledge in COVID-19 prevention. As per above data the grafic is below

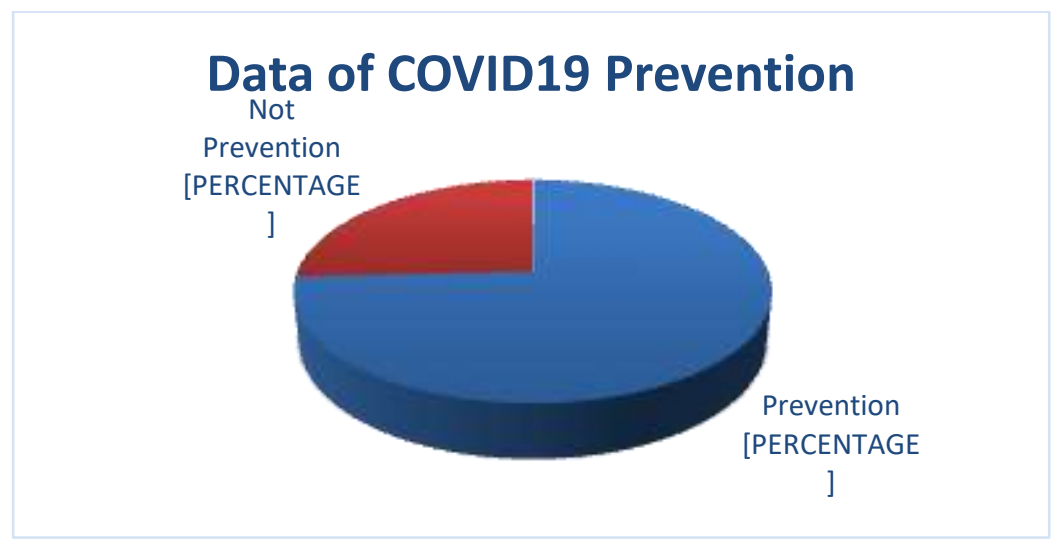

Fig. 2. Data of COVID19 prevention

From above grafic, $26 \%$ of respondent are not prevention concerning COVID19 and 74 Person are prevention concerning COVID19. Knowledge of balanced nutrition is knowledge about food and nutrients, sources of nutrients in food, safe food consumed, and how to manage food well [18]. The results showed that the majority of respondents had good nutritional knowledge. 
Corona virus actually almost nothing to do with the diet of Indonesian people. [19] explains that there is no evidence that shows that food is part of the corona virus transmission route. although food is not an agent of the spread of the corona virus and is not the cause of the disease, but diet is very closely related to the resistance of the human body when attacked by the corona virus. Someone with a good diet, of course, has better endurance compared to someone who has a bad diet. This can result in the level of fatality of the corona virus attack, to the point of causing death. In someone who has a poor diet, both malnourished and who already has a congenital disease such as diabetes, has a higher risk of death. In someone who has good endurance, the corona virus may just stick to it, but the person does not experience any symptoms.

The eating patterns of some Indonesian people are not good. Basic Health Research conducted by the [20] shows that not a few Indonesian citizens are malnourished or even suffer from diabetes. This group is at risk of experiencing fatal health problems when attacked by the corona virus.

According to research [21] there is no relationship between age and knowledge about Covid-19 prevention. Age is not a limiting factor for community information sources in South Kalimantan to gain knowledge about Covid-19 prevention, because people with different age categories make it possible to have the same activity and information exposure [22].

\section{Conclusions}

Age is not a major factor in inhibiting community information sources in Semarang to gain knowledge about Covid-19 prevention, because people with different age categories make it possible to have the same activity and exposure to information. This study concludes that there is a relationship between adolescent nutritional knowledge in COVID-19 prevention.

Thank you to the people of Semarang City who have supported and participated in this research during the pandemic at the time the research was conducted.

\section{References}

[1] World Health Organization (WHO), "Novel Coronavirus," World Heal. Organ., no. February, p. 2019, 2020, [Online]. Available: https://www.who.int/indonesia/news/novel-coronavirus/qa-forpublic.

[2] H. A. Rothan and S. N. Byrareddy, "The epidemeology and pathogensis of coronavirus (Covid-19) outbreak," J. Autoimmun., vol. 109, no. January, pp. 1-4, 2020.

[3] H. Nielsen and K. M. Bronwen Player, "Guidance on routine immunization services during COVID-19 pandemic in the WHO European Region," 2009, [Online]. Available: http://www.euro.who.int/pubrequest.

[4] Brunner and suddarth, "keperawatan Medical Bedah," Eb. EGC, pp. 0-115, 2010.

[5] World Health Organization (WHO), "Coronavirus disease (COVID-19) in Indonesia," 2020. https://www.who.int/indonesia.

[6] E. Termini et al., “No 主観的健康感を中心とした在宅高齢者における 健康関連指標に関す る共分散構造分析Title,” vol. 21, no. 1, pp. 1-9, 2020.

[7] S. Tian et al., "Characteristics of COVID-19 infection in Beijing," J. Infect., vol. 80, no. 4, pp. 401-406, 2020, doi: 10.1016/j.jinf.2020.02.018.

[8] KEMENKES RI, "kesiapsiagaan menghadapi kejadian COVID-19," 2020. https://www.kemkes.go.id/. 
[9] J. He et al., "Characteristic Electrocardiographic Manifestations in Patients With COVID-19," Can. J. Cardiol., vol. 36, no. 6, p. 966.e1-966.e4, 2020, doi: 10.1016/j.cjca.2020.03.028.

[10] L. A. A. Coutinho, C. P. M. Porto, and A. P. T. R. Pierucci, "Critical evaluation of food intake and energy balance in young modern pentathlon athletes: A cross-sectional study," J. Int. Soc. Sports Nutr., vol. 13, no. 1, pp. 1-8, 2016, doi: 10.1186/s12970-016-0127-x.

[11] B. M. Matthew J. C. Crump Nicholaus P. Brosowsky, "Reproducing the Location-Based ContextSpecific Proportion Congruent Effect for Frequency Unbiased Items: A Reply to Hutcheon and Spieler (2016)," 2016, [Online]. Available: https://journals.sagepub.com/doi/abs/10.1080/17470218.2016.1206130.

[12] R. M. and C. R. Krystle E. Zuniga, Darcy L. Downey, "Need for and Interest in a Sports Nutrition Mobile Device Application Among Division I Collegiate Athletes," 2016, [Online]. Available: https://journals.humankinetics.com/view/journals/ijsnem/27/1/article-p43.xml.

[13] S. Kim, J. H. Yang, and G. H. Park, "Eating frequency is inversely associated with BMI, waist circumference and the proportion of body fat in Korean adults when diet quality is high, but not when it is low: Analysis of the Fourth Korea National Health and Nutrition Examination Survey (KNHANES IV)," Br. J. Nutr., vol. 119, no. 8, pp. 918-927, 2018, doi: $10.1017 / \mathrm{S} 0007114518000557$.

[14] Y. Wang et al., "Remdesivir in adults with severe COVID-19: a randomised, double-blind, placebocontrolled, multicentre trial," Lancet, vol. 395, no. 10236, pp. 1569-1578, 2020, doi: 10.1016/S0140-6736(20)31022-9.

[15] A. E. Damayanti, Hubungan Citra Tubuh, Aktivitas Fisik, Dan Pengetahuan Gizi Seimbang Dengan Status Gizi Remaja Putri. 2016.

[16] M. Nova and R. Yanti, "HUBUNGAN ASUPAN ZAT GIZI MAKRO DAN PENGETAHUAN GIZI DENGAN STATUS GIZI PADA SISWA MTs.S AN-NURKOTA PADANG,”J. Kesehat. PERINTIS (Perintis's Heal. Journal), vol. 5, no. 2, pp. 169-175, 2018, doi: 10.33653/jkp.v5i2.145.

[17] A. Mahasiswi, L. P. P. Graha, W. Dan, S. Inggris, and D. Semarang, "Online di : http://ejournals1.undip.ac.id/index.php/jnc mahasiswi Program Studi Sastra Inggris Undip sedangkan mahasiswi Program Studi Sastra Inggris Graha Wisata Semarang dan mahasiswi Sastra Inggris Universitas Diponegoro Semarang tidak Graha Wisata Se," vol. 2, 2013.

[18] Prof. Dr. Soekodjo Notoatmodjo, ilmu perilaku kesehatan. 2014.

[19] J. Whirworth, "Food safety issues unclear as U.K. nears Brexit; U.S. food safety regs questioned," 2020 https://www.foodsafetynews.com/2019/03/food-safety-issues-up-in-the-air-as-u-kapproaches-brexit-u-s-food-targeted/.

[20] K. Riskesdas, "Hasil Utama Riset Kesehata Dasar (RISKESDAS)," J. Phys. A Math. Theor., vol. 44, no. 8, pp. 1-200, 2018, doi: 10.1088/1751-8113/44/8/085201.

[21] A. Wulandari et al., "Hubungan Karakteristik Individu dengan Pengetahuan tentang Pencegahan Coronavirus Disease 2019 pada Masyarakat di Kalimantan Selatan,” J. Kesehat. Masy. Indones., vol. 15 , no. 1, p. 42, 2020, doi: 10.26714/jkmi.15.1.2020.42-46

[22] V. Nurmala, I., Rahman, F., Nugroho, A., Erlyani, N., Anhar, Promosi Kesehatan. 2018. 